\title{
3 \\ EU Financial Engineering and Microfinance Non-financial Service: A Case Study
}

Maria Claudia Costantini, Maria Doiciu, Stefanie Lämmermann, Andrea Nardone and Giovanni Nicola Pes

\subsection{The ESF and the credit access of microenterprises}

\subsubsection{The problem of access to credit for microenterprises}

Small and medium-sized enterprises (SMEs) represent 99.8 per cent of the total number of enterprises in Europe and play a key role in terms of economic development and creation of jobs, by accounting for 57.6 per cent of added value in EU-27 and more than two thirds of jobs created in the private sector (Table 3.1). Over 90 per cent of European businesses are microenterprises with less than ten employees, whose importance is particularly significant in South European countries such as Italy, Spain and Portugal. ${ }^{1}$

While large businesses have ready access to equity capital markets to support their investment projects, SMEs - and, in particular, microenterprises - cannot access them and, therefore, are heavily reliant on bank lending: in 2013, bank lending (or other forms of financing such as leasing and factoring) represented the only source of funding for 54 per cent of micro, small and medium-sized enterprises in the European Union, and 75 per cent of them used at least one form of debt financing. ${ }^{2}$ On the other side, equity financing was little used, only by 5 per cent of the EU enterprises in 2013, in particular by SMEs with a stock market listing and those with a turnover exceeding €50 million, but also by the so-called gazelles, that is, SMEs less than five years old which have grown at over 20 per cent per annum. As we underline in the previous chapters, promoting access to credit for microenterprises and SMEs is one of the key priorities of the European Union strategy for growth. ${ }^{3}$ Moreover, the European Commission itself, in its communication 
Table 3.1 Enterprises, employees and added value, EU-27, 2012

\begin{tabular}{|c|c|c|c|c|c|c|}
\hline & $\begin{array}{c}\text { Micro } \\
\text { enterprises }\end{array}$ & $\begin{array}{c}\text { Small } \\
\text { enterprises }\end{array}$ & $\begin{array}{l}\text { Medium- } \\
\text { sized } \\
\text { enterprises }\end{array}$ & Total SMEs & $\begin{array}{c}\text { Large } \\
\text { enterprises }\end{array}$ & Total \\
\hline $\begin{array}{l}\text { Number } \\
\%\end{array}$ & $\begin{array}{c}18,783,480 \\
92.1\end{array}$ & $\begin{array}{c}1,349,730 \\
6.6\end{array}$ & $\begin{array}{c}222,628 \\
1.1\end{array}$ & $\begin{array}{c}20,355,839 \\
99.8\end{array}$ & $\begin{array}{c}43,454 \\
0.2\end{array}$ & $\begin{array}{c}29,399,291 \\
100\end{array}$ \\
\hline \multicolumn{7}{|c|}{ Number of employees } \\
\hline $\begin{array}{l}\text { Number } \\
\%\end{array}$ & $\begin{array}{c}37,484,458 \\
28.7\end{array}$ & $\begin{array}{c}26,704,352 \\
20.5\end{array}$ & $\begin{array}{c}22,615,906 \\
17.3\end{array}$ & $\begin{array}{c}86,814,717 \\
66.5\end{array}$ & $\begin{array}{c}43,787,013 \\
33.5\end{array}$ & $\begin{array}{c}130,601,730 \\
100\end{array}$ \\
\hline \multicolumn{7}{|c|}{ Added value at factor cost } \\
\hline $\begin{array}{l}\text { Million } € \\
\%\end{array}$ & $\begin{array}{c}1,242,72 \\
21.1\end{array}$ & $\begin{array}{c}1,076,388 \\
18.3\end{array}$ & $\begin{array}{c}1,076,270 \\
18.3\end{array}$ & $\begin{array}{c}3,395,383 \\
57.6\end{array}$ & $\begin{array}{c}2,495,926 \\
42.4\end{array}$ & $\begin{array}{c}5,891,309 \\
100\end{array}$ \\
\hline
\end{tabular}

Source: Authors' elaboration on Eurostat, National Statistical Offices data, DIW, DIW econ, London Economics.

"Europe 2020", ${ }^{4}$ points out that the recent economic crisis has almost halved the potential for growth of these enterprises, forcing them to resize their investment plans, due both to sluggish demand and lack of funding (credit crunch). In particular, the sovereign debt crisis resulted in a severe shortage of funds available on the markets for European banks as well as reduced opportunities to access credit for households and businesses alike, many of which - especially microenterprises - have seen their creditworthiness fall lower. ${ }^{5}$

Recent quantitative surveys ${ }^{6}$ highlight that although restrictions on the supply of credit are showing signs of gradual attenuation, the bank policies, especially towards smaller enterprises, are still influenced by the perception of high credit risk; as a result, such enterprises are still struggling to access credit. The feedback received from entrepreneurs on cases of loan refusal confirms the SMEs negative perception on the possibility of obtaining external funding. In particular, about one third of the SMEs participating in the survey claim not to be able to get the full credit amount needed to implement their investments in 2013, and 7 per cent of them (mainly micro start-ups) did not even apply for a loan as they were positive that their applications would be rejected.

All SMEs managers who participated in the survey were asked to evaluate a pre-supplied list of seven potential problems ${ }^{7}$ that their companies might be currently facing and to choose among the most pressing issues on the list. Fifteen per cent of the EU SMEs regard access to credit as the second most pressing problem, preceded only by finding customers (Chart 3.1). However, there was a lot of variation across countries with regard to the evaluation of SMEs for access to finance. In fact, while France, the 


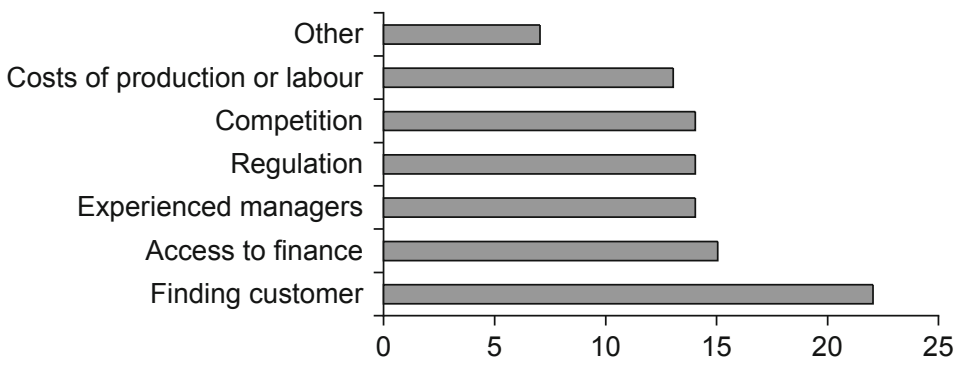

Chart 3.1 Main criticalities perceived by European SMEs, 2013 (percentage values)

Source: Authors' elaboration on EC (2013), SMEs Access to Finance survey.

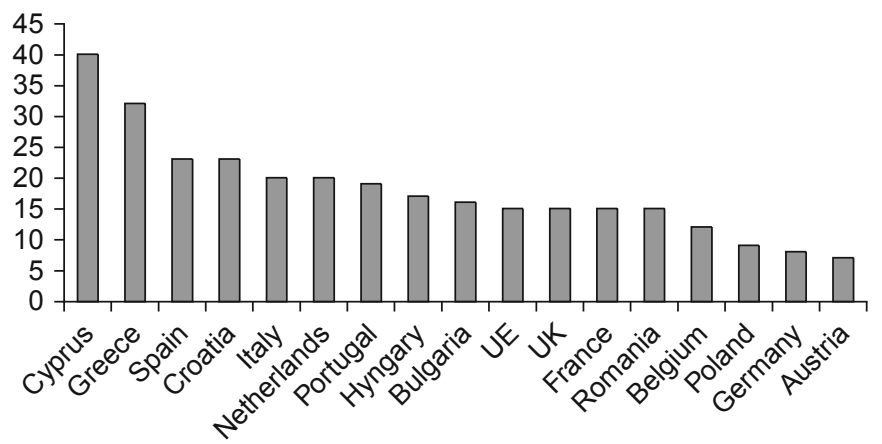

Chart 3.2 European SMEs regarding access to credit as the most pressing problem, 2013 (percentage values)

Source: Authors' elaboration on EC (2013), SMEs Access to Finance survey.

United Kingdom and Romania are levelled around the average percentage of 15 per cent, the figures become 32 per cent in Greece, 23 per cent in Spain, 20 per cent in Italy, Ireland and the Netherlands and then decrease to 9 per cent in Poland and 8 per cent in Germany (percentage values for the main European countries are indicated in Chart 3.2).

Recent data provided by the Bank Lending Survey ${ }^{8}$ on the bank loan performance in the EU area in the first quarter of 2014 do not show significant changes in the restrictive policy adopted by EU banks in the provision of credit, which continues to be affected by the perception of high credit risk, especially towards smaller and microenterprises. However, the results of other econometric surveys ${ }^{9}$ indicate that the difficulties met by SMEs and microenterprises as well as young businesses to access external 
financing cannot be totally related to risk perception, as these issues may persist even in cases of financial performance equal to that of mediumsized and large companies. According to these studies, the European bank credit market is characterised by a number of imperfections that are likely to originate from a series of information asymmetries: on one side, banks are not prone to lend if they are unable to obtain sufficient financial information on the profitability of investments by enterprises; on the other, enterprises are discouraged from applying for loans due to a lack of information on sources of financing and, often, also because they perceive a lack of willingness to lend by the banks.

\subsubsection{European Social Fund and access to credit of microenterprises}

The problem of access to credit for SMEs and microenterprises is at the centre of the EU policies for growth, employment and social inclusion. To solve it, the European Commission has activated a broad range of programmes and allocated resources to be provided by the funds directly managed by the commission itself (e.g., the COSME programme and progress microfinance for the microcredit sector) and by the structural funds managed by the individual state members and regions. Among the latter, the European Regional Development Fund (ERDF) undoubtedly plays a key role in the provision of financial support to enterprises, as it is specifically dedicated to financing investments made by enterprises, but also the European Social Fund (ESF), within the framework of its social inclusion objectives, which allows activating specific measures to access credit (and microcredit) within the regional operational programmes, especially for disadvantaged subjects who are willing to start or consolidate microenterprises or self-employment initiatives.

As is known, the essential objective of the European Social Fund is to "promote high levels of employment and job quality, improve access to labour market, support the geographical and occupational mobility of workers and facilitate their adaptation to industrial change and changes in production systems needed for sustainable development, encourage a high level of education and training for all and support the transition from education to employment for young people". ${ }^{10}$

The ESF, therefore, "benefits people, including disadvantaged people, such as the long-term unemployed, people with disabilities, migrants, ethnic minorities, marginalised communities and people of all ages facing poverty and social exclusion. The ESF also provides support to workers, enterprises, including actors in the social community and entrepreneurs, as well as to systems and structures with a view to facilitating their adaptation to new challenges, including reducing skill mismatches 
and promoting good governance, social progress, and the implementation of reforms, in particular in the fields of employment, education, training and social policies". ${ }^{11}$

It is quite a broad mission, which expressly includes support to SMEs and microenterprises also through the "use of financial instruments, including microcredit and guarantee funds"12 according to art. 37 of EU regulation no. $1303 / 2013 .{ }^{13}$ This policy to support SMEs and microenterprises, as well as all other measures co-financed by the ESF, refers to 4 out of 11 thematic objectives (TOs) identified by art. 9 of the aforementioned regulation no. 1303/2013 to implement the EU strategy for smart, sustainable and inclusive growth. In particular, the following:

- TO no. 8: "Promoting sustainable and quality employment and supporting labour mobility";

- TO no. 9: "Promoting social inclusion, combating poverty and any discrimination";

- TO no. 10: "Investing in education, training and vocational training for skills and lifelong learning";

- TO no. 11: "Enhancing institutional capacity of public authorities and stakeholders and efficient public administration".

For each of these objectives, art. 3 of EU regulation no. 1304/2013 of the Social European Fund, provides for an articulated series of investment priorities (see Box 3.1).

Box 3.1 Thematic objectives and investments priorities of the European Social Fund (EU regulation no. 1304 of 17 December 2013, art. 3)

"Promoting sustainable and quality employment and supporting labour mobility" (TO no. 8), by facilitating:

- Access to employment for job-seekers and inactive people, including the long-term unemployed and people far from the labour market, also through local employment initiatives and support for labour mobility.

- Sustainable integration into the labour market of young people, in particular those not in employment, education or training, including young people at risk of social exclusion and young people from marginalised communities, including through the implementation of the Youth Guarantee.

- Self-employment, entrepreneurship and business creation including innovative micro, small and medium-sized enterprises.

- Equality between men and women in all areas, including in access to employment, career progression, reconciliation of work and private life and promotion of equal pay for equal work.

- Adaptation of workers, enterprises and entrepreneurs to change. 
- Active and healthy ageing.

- Modernisation of labour market institutions, such as public and private employment services, and improving the matching of labour market needs, including through actions that enhance transnational labour mobility as well as through mobility schemes and better cooperation between institutions and relevant stakeholders.

"Promote social inclusion, combating poverty and any discrimination" (TO no. 9), by facilitating:

- Active inclusion, including with a view to promoting equal opportunities and active participation, and improving employability.

- Socio-economic integration of marginalised communities such as the Roma.

- Combating all forms of discrimination and promoting equal opportunities.

- Enhancing access to affordable, sustainable and high-quality services, including health-care and social services of general interest.

- Promoting social entrepreneurship and vocational integration in social enterprises and the social and solidarity economy in order to facilitate access to employment.

- Community-led local development strategies.

"Investing in education, training and vocational training for skills and lifelong learning" (TO no. 19):

- Red ucing and preventing early-school leaving and promoting equal access to good quality early-childhood, primary and secondary education including formal, non-formal and informal learning pathways for reintegration into education and training.

- Improving the quality and efficiency of, and access to, tertiary and equivalent education with a view to increasing participation and attainment levels, especially for disadvantaged groups.

- Enhancing equal access to lifelong learning, for all age groups in form, nonformal and informal settings, upgrading the knowledge, skills and competences of the workforce, and promoting flexible learning pathways including through career guidance and validation of acquired competencies.

- Improving the market labour relevance of education and training systems, facilitating the transition from education to work, and strengthening vocational education and training systems and their quality, including through mechanisms for skills anticipation, adaptation of curricula and the establishment and development of work-based learning systems.

"Enhancing institutional capacity of public authorities and stakeholders and efficient Public Administration" (TO no. 11):

- Investment in institutional capacity and in the efficiency of public administrations and public services at the national, regional and local levels with a view to reforms, better regulation and good governance.

- Capacity building of all stakeholders delivering education, lifelong learning, training, employment and social policies, including through sectorial and territorial pacts to mobilise for reform at national, regional and local level. 
As you can see, in light of the above objectives, the support provided to enterprises to facilitate access to credit is part of a broader vision targeting social inclusion, training, education and increased employment opportunities for disadvantaged groups, such as young people, women, longterm unemployed individuals and migrants. These objectives have been adopted by a number of EU member states within their ESF regional operational programmes (PORs) within the programming period 2007-2013, with the aim of creating microcredit funds to support certain categories of disadvantaged subjects as identified by the aforementioned EU regulations. According to surveys carried out at a European level, which are referred to herein as well, Italy seems to be one of the most active EU countries in this field, as it included specific microcredit measures within its ESF regional operational programmes. In particular, the central and southern Italian regions included revolving or guarantee funds co-financed by the European Social Fund, which will continue to operate also in the current programming period 2014-2020. Below you can find a summary of such measures, their objectives and operational methods.

Box 3.2 For ESF Italy 2007-2013 providing from microcredit measures

\section{REGION ABRUZZO}

Objectives: To support local microenterprises and self-employment by financing start-ups and promoting new investments and/or the consolidation of existing businesses, for all those subjects, whether individuals or legal entities, who are unable to access traditional credit services due to personal and/or objective reasons.

Beneficiaries: Existing microenterprises or being formed and self-employed workers.

Financial instrument: Revolving fund for the provision of unsecured loans.

Financial conditions: Maximum loan amount is $€ 10,000$ for individuals and $€ 25,000$ for legal entities; maximum duration 60 months; 1 per cent interest rate.

\section{REGION CAMPANIA}

Objectives: To support start-ups and implementation of new investments for existing enterprises, including spin-offs, for categories of subjects who struggle to access traditional credit and are affected by disadvantaged conditions.

Beneficiaries: Individuals willing to start new microenterprises, existing microenterprises or companies being formed (including spin-offs), enterprises operating in the service sector (social associations and cooperatives), whether existing or being formed. 
Financial instrument: Revolving fund for the provision of unsecured loans. Financial conditions: Maximum loan amount is $€ 25,000$; maximum duration is 60 months; interest-free.

\section{REGION APULIA}

Objectives: To support access to small-amount loans to promote a regional development model based on high human capital intensity and low environmental impact, rewarding enterprises created by young people and women and supporting innovative and sustainable conversion of traditional businesses.

Beneficiaries: Existing microenterprises.

Financial instrument: Revolving fund for the provision of unsecured loans.

Financial conditions: Maximum loan amount is $€ 25,000$; maximum duration is 60 months; interest rate equal to 70 per cent of the EU reference rate.

\section{REGION BASILICATA}

Objectives: To promote an innovative and integrated action to support local microenterprises, cooperatives and unemployed/inactive subjects and create new enterprises, through a support and guarantee fund co-financed by the ESF with the aim of facilitating access to credit for microenterprises and support new entrepreneurs, including initiatives started by disadvantaged subjects, by way of the following: (a) provision of low-interest loans; (b) provision of guarantees.

Beneficiaries: Non-bankable subjects who set up enterprises, social enterprises and self-employed workers.

Financial instrument: Support and guarantee fund.

Financial conditions: Maximum loan amount is $€ 25,000$; maximum duration is 60 months; interest-free.

\section{REGION CALABRIA}

Objectives: To promote microcredit programmes as an instrument to fight poverty and social exclusion in order to develop participation and solidarity initiatives to support disadvantaged groups; to support employment through self-employment initiatives and the creation of microenterprises; to support initiatives aimed at enhancing local development potential.

Beneficiaries: Disadvantaged workers, disabled workers, immigrants, inmates, alcohol and drug addicts.

Financial instrument: Guarantee fund and interest-subsidy fund.

Financial conditions: Maximum loan amount is $€ 25,000$; maximum duration is 60 months; fixed interest rate negotiated with the banks. The fund guarantees 80 per cent of the loans and provides 100 per cent interest subsidy. 


\section{REGION SARDINIA}

Objectives: To support start-ups or the implementation of new investments in existing businesses, for categories of subjects who struggle to access credit and are affected by disadvantaged conditions.

Beneficiaries: Workers over 50 years old, young unemployed or inactive workers, off-workers, unemployed or inactive workers, women, migrants, single-parent families, new entrepreneurs.

Financial instrument: Revolving fund for the provision of unsecured loans.

Financial conditions: Maximum loan amount is $€ 25,000$; maximum duration is 60 months; interest-free.

Source: Authors' elaboration.

\subsection{The ESF and access to credit for microenterprises: a case study from Germany}

During the last two decades a strong microcredit sector has developed in Germany. Small microcredit pilot projects already emerged in the 1990s and early 2000. Around 2005 the sector came to a consolidation; finally, from 2010 on it was rolled out on a nationwide level. In each of these phases, ESF funding played a pivotal role, especially for developing, testing and implementing new products, tools and processes. It is fair to say that the German microcredit sector would not exist today without support from ESF. The following paragraph highlights the role that ESF played in the development of microcredit in Germany.

\subsubsection{History of microfinance in Germany}

The pilot phase (2000-2004)

Already in the 1990s some scattered microcredit initiatives were set up around Germany (such as Goldrausch, providing microloans to women). ${ }^{14}$ From the year 2000 on, more and more local and regional business support organisations realised that their clients faced difficulties in accessing finance for setting up or developing their small enterprise, especially entrepreneurs starting out of unemployment. These organisations therefore developed microcredit operations in addition to their consulting and training activities. Organisations such as Enigma (Hamburg), ${ }^{15}$ Verbund Enterprise (Brandenburg), ${ }^{16}$ EXZET (Stuttgart) ${ }^{17}$ and $K I Z$ (Offenbach) ${ }^{18}$ created first pilot microcredit programmes in cooperation with different banks and with financial support from German public bodies such as the Federal Employment Agency, foundations as well as EU funds, notably ESF. In the pilot phase (2000-2004) 
so-called development partnerships were established in the frame of the ESF EQUAL programme in order to develop a one-stop-shop system for solo entrepreneurs in Germany, including financial support. In this context, a range of studies analysing and comparing the microfinance experience of existing pilot projects was carried out. Knowledge about microfinance practice in other EU countries was brought in, too. By doing so, microcredit was lifted to the attention of the German public, highlighting its main characteristics and success factors such as unbureaucratic procedures, flexibility, alternative guarantees, step loan provision and additional business support. Starting from the idea of making available easy access to capital, Deutsches Mikrofinanz Institut (DMI), ${ }^{19}$ a nationwide microfinance network was created in April 2004. The first project of the association was to conduct a "test run" in order to develop a range of microfinance products and methods. First, about 10 members actively joined this pilot phase. Up to 30 other members assisted them voluntarily through collaboration and membership fees. Based on this support structure it was possible to reach a joint start of microfinance at different locations and trigger joint learning processes for the benefit of all involved actors. DMI, in close cooperation with the ethical-ecological bank GLS, developed a microfinance cooperation model for Germany and in June 2004 it was decided to set up the first microfinance fund. At first, capital was injected by GLS Bank and 80 private persons close to GLS. Thus, at the end of 2004, €500,000 were made available for microloan disbursement through the GLS Microfinance Fund.

\section{The consolidation phase (2005-2009)}

In the second EQUAL funding period the microfinance cooperation model was consolidated. The model is based on the cooperation of four different partners:

- So-called microfinance institutions (MFIs: business counselling companies, start-up centres, regional business initiatives and so on) carry out the client support, from the first contact till full repayment of the loan. The MFIs administer the loan securities, are responsible for constant monitoring of the loans and take over a substantial part of the risk.

- Due to German banking law a cooperating bank distributes the microloans upon the MFIs' recommendation (low risk and high scale).

- A guarantee fund covers 100 per cent of the risk for the bank.

- The supervising organisation assures the quality of the microloan operations through training, accreditation and benchmarking of the MFIs. 

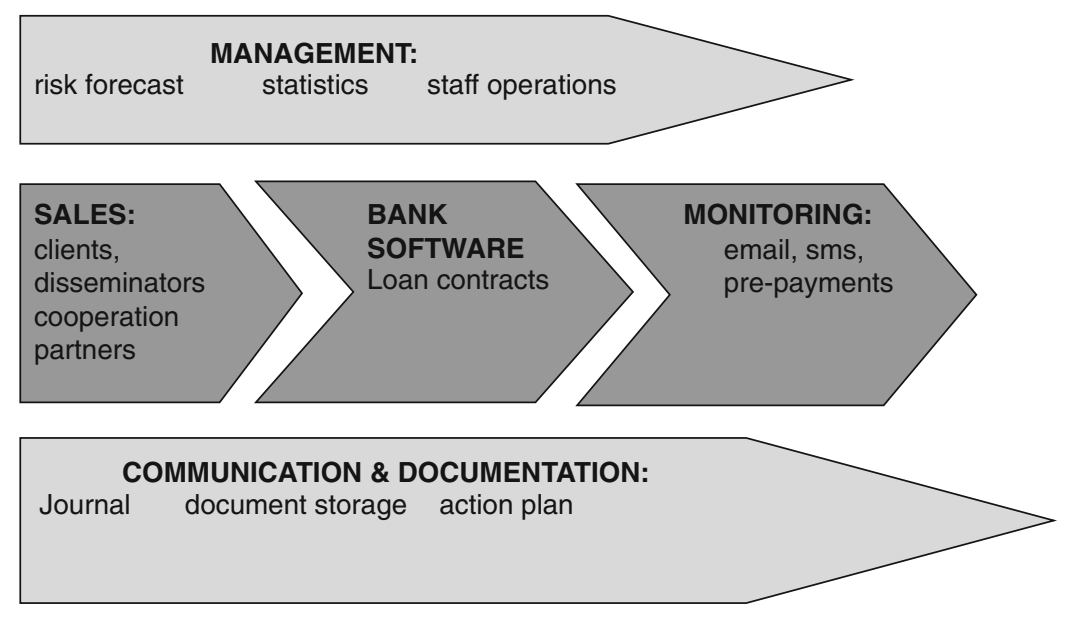

Figure 3.1 Overview of DMI MIS Intherpro

Source: Authors' elaboration.

In 2006, the Federal Ministry of Labour and Social Affairs, the Federal Ministry of Economy and Technology and the federal development bank $\mathrm{KfW}$ joined as investors of the microfinance fund established in 2004. They topped up the fund with $€ 2$ million and the fund was renamed Mikrofinanzfonds Deutschland (Microfinance Fund Germany).

In order to monitor and manage the loans the DMI network developed a sophisticated client monitoring and risk management system called Inthepro with initial funding from EQUAL (Figure 3.1). Inthepro maps the whole credit process, from the first contact until full repayment of the loan. It enables the MFIs to carry out a partly automatised, detailed client monitoring procedure; this is completed by a risk management and benchmarking system that classifies all outstanding loans into specific risk categories. Through monthly benchmarking the system ensures quality management and early-warning for MFIs as well as higher-level bodies.

Then, in autumn 2007, DMI launched Projekt 5000 (Project 5000 Microfinance as an instrument to solve sociopolitical problems), a nationwide campaign with the aim of scaling up microfinance by developing a growth strategy and linking practitioners and supporters of microfinance. The project would end once the 5,000th microloan handed out. It was at the beginning of 2010 that this project received real impetus. 


\section{Roll-out (2010-today)}

In January 2010, based on a study about access to finance for microenterprises and self-employed people, the Federal Ministry of Labour and Social Affairs and the Federal Ministry of Economy and Technology decided to start a new programme with a similar set-up as in 2004-2006: Mikrokreditfonds Deutschland (Microcredit Fund Germany). In total, $€ 100$ million were provided as a guarantee fund, 60 per cent coming from national European Social Fund and 40 per cent from the German government. The aim of the fund was to sustainably establish a nationwide offer of microcredits in Germany and disburse 15,000 microloans until 2015. The fund considerably improved the operating environment for MFIs.

MFIs active under the fund need accreditation from DMI and have to cover up to 20 per cent of the defaults (first loss). In return they receive a gratification payment (depending on the repaid loan volumes) and a (decreasing) item fee for each loan handed out, which the MFIs can use to cover part of their institution building costs. Besides, in the first two years of operation of the microcredit fund, from 2010 to 2012, the DMI network led a microcredit project in the frame of the large-scale ESF programme IDA: Integration durch Austausch (Integration through exchange). The project enabled the sector to scale up its know-how through exchange visits with other European countries as well as studies and pilot projects on topics such as processing cost, sustainability, transparency, outreach to target groups, risk management, scoring models and quality labels (EU Code of Good Conduct for Microcredit Provision). Through meetings, workshops and conferences, the lessons learnt on a Europe-wide level were shared with over 100 German microfinance practitioners from 40 MFIs as well as representatives from the banking sector, political actors and administrators. The German Mikrokreditfonds is today celebrated as great success all over Europe. From 2010 to 2013 the MFIs supported more than 16,500 German microentrepreneurs through loans. Unfortunately, since 2013 the microfinance activity has declined. The reasons are manifold. The system turned out to be complex, and too many incentives had been given for quick growth, while the experience and knowledge of the DMI network was neglected. Since 2013, the MFIs have had to cope with high lack of planning reliability due to several interruptions of the Mikrokreditfonds programme.

\section{Appraisal of ESF support for microcredit in Germany}

Microcredit aims at supporting disadvantaged people who wish to set up or develop a business; it is therefore an important instrument of labour 
Table 3.2 Loan volumes since 2005 (preliminary numbers)

\begin{tabular}{lrrr}
\hline Period & Loans & \multicolumn{1}{c}{ Euro } & MFIs \\
\hline 2005 & 12 & $106,050.00$ & 5 \\
2006 & 38 & $265,535.00$ & 7 \\
2007 & 89 & $562,694.00$ & 9 \\
2008 & 119 & $788,560.00$ & 12 \\
2009 & 287 & $1,962,461.00$ & 12 \\
2010 & 1,748 & $9,807,770.00$ & 42 \\
2011 & 4,869 & $29,720,551.00$ & 57 \\
2012 & 5,520 & $33,700,000.00$ & 60 \\
2013 & 4,520 & $30,198,120.00$ & 42 \\
(Preliminary numbers) & & & \\
Total & 17,202 & $107,111,741.00$ & \\
\hline
\end{tabular}

Source: Authors' elaboration.

market policy. The ESF, as stressed in Chapter 2, is Europe's main instrument for supporting jobs, helping people get better jobs and ensuring fairer job opportunities for all EU citizens. It is therefore exactly the right funding instrument when it comes to supporting microcredit in Europe. The German microcredit sector has benefited from ESF funding in several ways. First of all, within the framework of the EU community initiative EQUAL (2002-2007), standardised microlending processes were designed as well as products and tools adapted to the needs of the clients. These were subsequently tested and implemented by MFIs in different regions and for different target groups. They build the basis of what constitutes the German microfinance sector today. Secondly, ESF gave an important input to controlling and supervising the high quality of the microloan provision, through the development of the DMI Inthepro software and accreditation system. The DMI accreditation and training system has been acknowledged as good practice in microfinance in Europe. Moreover, with Inthepro, a powerful management information system now exists. It enables the MFIs to actively support their clients in the loan repayment while holding the cost as low as possible, and provides the possibility of comparison and mutual learning amongst all MFIs. Finally, ESF has shown its usefulness as a financial engineering instrument in Germany. Although the German experience has made clear that several parameters need to be adapted for such a programme to be successful and sustainable over time, a strong microcredit sector has emerged, with devoted MFIs who face the 
harsh reality in their everyday work - clients who cannot get finance, either from private nor public promotional banks, and who urgently need microfinance to establish their business. More than 17,000 entrepreneurs have received an average microcredit of around $€ 6,000$ under the various, national microfinance funds since 2005; in Germany 33 per cent of them are women, and 35 per cent have migrant background. Based on the assumption that one microloan creates or maintains two jobs, this means that microcredit has saved nearly 35,000 jobs in the last ten years in Germany. There is strong demand for a microcredit in Germany. Much still needs to be done in order to completely close the funding gap for small enterprises and self-employed people. Although much has been achieved, further ESF-funding is needed in order to back MFIs when it comes to developing their products and services and successfully reach out to their target groups.

\subsection{Microfinance and non-financial services: the European resources to sustain non-financial services}

The EU has long committed itself in strengthening the skills of existing entrepreneurs, new entrepreneurs and potential entrepreneurs. In 2006, within the project DG Enterprise and Industry, the European Commission entrusted a group of experts with the task of analysing the best practices of management capacity building in order to develop and support the competitiveness of the European SMEs. In its final report (EC, 2006, p. 29), ${ }^{20}$ the group of experts proposed a set of 16 recommendations, aimed at all actors involved.

In particular, the following recommendations were directed to business support providers:

I. Promote courses and programmes to help assess enterprises' competitive positioning and directly impacting their profitability.

II. Make sure that all phases of the enterprise life cycle are covered.

III. Promote alliances with bigger companies.

IV. Facilitate the creation of networks and promote their use.

V. Schedule training so that small business managers can actually attend.

VI. Make good use of opportunities offered by e-learning.

VII. Business support service providers need to improve the marketing of their services. 
While the recommendations directed to business and trade associations and individual entrepreneurs were as follows:

VIII. Identify and acquire information or knowledge matching the specific needs of the businesses.

IX. Identify useful courses and attend some (no excuses), business associations should contribute to assess the quality and relevance of the training offered.

X. Businesses need to be aware that they may gain additional knowledge through means other than courses and consultants - with an added bonus: it can be cheaper.

In 2007, the European Commission, in the Communication from the Commission to the Council, the European Parliament, the European Economic and Social Committee and the Committee of the Regions of 13 November 2007 - a European initiative for the development of microcredit in support of growth and employment (EC, 2007), ${ }^{21}$ stressed the importance of microcredit both with regard to the implementation of strategies that may favour growth and the creation of jobs and the promotion of social integration. In this perspective, in its 2007 communication the European Commission recommended EU institutions and the single member countries to carry out measures supporting microcredit through the following directories:

1. Improve the legal framework and institutional environment of the member countries.

2. Change the background conditions and promote a business-friendly environment.

3. Promote the dissemination of best practices, including training.

4. Increase capitals available to the microcredit providers.

In particular, the commission stressed the necessity of "increasing the chances of success of new microenterprises through training, tutoring and development of business support services" (EC, 2007, p. 9). ${ }^{22}$ Access to credit is definitely a major issue for new entrepreneurs and, generally, for all those subjects excluded from the traditional lending circuits, although not the only one. In fact, due to the complexity of the European entrepreneurial system, it is now necessary to provide the new entrepreneurs with skills and know-how they often lack. "Training, mentoring or coaching the new entrepreneurs are essential to improve the enterprise's chances of success" (EC, 2007, p. 8). ${ }^{23}$ 
However, in order to offer such services to microentrepreneurs, the microfinance providers must carefully analyse their financial sustainability and feasibility. The costs of such services, in fact, are unlikely to be borne by the commercial bank sector and the existing experiences at European level (such as the experiences in Italy and France) have highlighted the importance of the public and non-profit sectors in the promotion of non-financial services connected with microcredit.

The aforementioned communication already emphasised that a greater use of the resources provided by the FESR, the FSE (European Social Fund) and the FEASR (European Agriculture Fund for Rural Development) would be desirable to promote the business support services (EC, 2007, p. 8, 27). ${ }^{24}$ A further step away from their centralisation is represented by the adoption of the Small Business Act (EC, 2008) (25 $^{25}$ the European Commission in June 2008 within the broader Action Plan 2020 for enterprises.

The Small Business Act called on all EU member countries to step up and promote a business-friendly environment for the development and growth of the SMEs through the application of ten basic principles, which are meant to address, from an operational point of view, the differences between American and European SMEs in terms of growth and productivity. In particular, principle no. 4, entitled "Turning principles into policy action", states that "the EU and Member States should create a healthy environment where entrepreneurs and family businesses can thrive and entrepreneurship is rewarded. They need to care for future entrepreneurs better, in particular by fostering entrepreneurial interest and talent, particularly among young people and women, and by simplifying the conditions for business transfers" (EC, 2008, p. 5). ${ }^{26}$

In order to translate these principles into practice, the European Commission committed its efforts:

- to promote an entrepreneurial culture and facilitating exchanges of best practices in entrepreneurship education;

- to launch the European SME Week in 2009 - an umbrella for many campaign-type events that will take place throughout Europe;

- to activate the Erasmus for Young Entrepreneurs initiative in 2008, which aims to promote exchanges of experiences and training by giving nascent entrepreneurs the possibility to learn from experienced host entrepreneurs and improve their language skills;

- to establish a EU network of female entrepreneurship ambassadors, promote mentoring schemes to inspire women to set up their own businesses and promote entrepreneurship among women graduates (EC, 2008, p. 6). ${ }^{27}$ 
The European Commission has focused its attention on non-financial services; in fact, member states are invited to:

- stimulate innovative and entrepreneurial mindsets among young people by introducing entrepreneurship as a key subject in school curricula, particularly in general secondary schools, and ensure that it is correctly reflected in the teaching material;

- ensure that the importance of entrepreneurship is correctly reflected in teachers' training;

- step up cooperation with the business community in order to develop systematic strategies for entrepreneurship education at all levels;

- provide mentoring and support for business transfers;

- provide mentoring and support for female entrepreneurs;

- provide mentoring and support for immigrants who wish to become entrepreneurs (EC, 2008, p. 6). ${ }^{28}$

To encourage entrepreneurship, besides reducing bureaucratic, fiscal and administrative barriers, the European Commission invites the member countries to implement a long-term strategy entrusting non-financial services with a central role. To create and stimulate entrepreneurial culture, therefore, it is necessary to start from the new generations by implementing stable programmes and measures that may facilitate the creation of knowledge and skills. At the same time, it is absolutely imperative and necessary to implement mentoring and support services for some specific target groups, such as women and immigrates, who may be involved in the creation of start-ups, to improve their living conditions, fight economic and social vulnerability, support the entrepreneurial community in developing a systematic strategy that may facilitates a permanent and continuous development at all levels as well as the transition of entrepreneurial skills and activities between different generations.

\subsection{The new European plans}

The current economic-financial crisis gripping the whole continent prompted the European Union to provide a response in terms of economic policy. As we have previously observed, the European Commission emphasised (and still does) the importance of non-financial services as a tool to support the growth and development of businesses; the role of entrepreneurship as a drive for economic growth and the creation of 
jobs. In particular, the SMEs represent the most important source of new jobs; according to the figures released by the European Commission, in fact, they account for the creation of over 4 million new jobs (EC, 2013, p. 4). ${ }^{29}$

In the Entrepreneurship 2020 Action Plan, the commission remarks that propensity to entrepreneurship greatly varies among the various EU member countries, due to a variety of factors, such as difficulty to access credit, red tapes and burdensome administrative procedures, difficulties to relocate companies, fear of sanctions in the event of bankruptcy, poor knowledge of the structure of small and medium-sized enterprises, inadequate measures to support them, an educational system that does not provide the basic knowledge and background to start and develop an entrepreneurial career.

Within the same action plan, the European Commission detects a widespread tendency in the current market context to ignore, or not acknowledge in the right way, the entrepreneurial efforts and initiatives as well as a lack of rewards for successful entrepreneurs (EC, 2013, p. 4). ${ }^{30}$

The Entrepreneurship 2020 Action Plan emphasises three areas of immediate action:

1. Entrepreneurship education and training aimed at supporting the creation and development of businesses.

2. Strengthening of the market conditions for the benefit of entrepreneurs, removing all structural obstacles and providing them with support during the most important phases of the enterprise life cycle.

3. Reignite the entrepreneurship culture in Europe: foster and raise a new generation of entrepreneurs.

The first action (Table 3.3) moves from the premise that entrepreneurship represents a key subject within the European education framework (EP and EC, 2006). ${ }^{31}$ The action plan puts a particular emphasis on entrepreneurial education of young people as a fundamental instrument to promote that cultural change needed to support economic growth. Some authors (Jenner, 2012, p. 27) ${ }^{32}$ stressed out that young people who receive an entrepreneurship-oriented education are more bound to develop not only a higher knowledge of the business world but also additional skills and attitudes to operate in this sector, including creativity, a spirit of entrepreneurship, tenacity, teamwork, responsibility and superior risk-assessment capacity. 
Table 3.3 Main actions recommended by the European Commission to the member countries: action no. 1 - entrepreneurship education and training

\begin{tabular}{|c|c|}
\hline Scope & Actions to be undertaken \\
\hline $\begin{array}{l}\text { Action } 1 \\
\text { Entrepreneurship } \\
\text { education and training } \\
\text { aimed at supporting } \\
\text { the enterprise creation } \\
\text { and development }\end{array}$ & $\begin{array}{l}\text { - Ensure that "entrepreneurship"-related subjects and } \\
\text { teachings are included in the curricula of primary, } \\
\text { secondary, vocational, higher and post-degree } \\
\text { education by the end of } 2015 \text {. } \\
\text { - Offer students at least one opportunity to have an } \\
\text { entrepreneurial experience before they complete their } \\
\text { compulsory education cycle. } \\
\text { - Boost entrepreneurship training for young people } \\
\text { and adults alike within the educational system, } \\
\text { by using the resources provided by EU structural } \\
\text { funds, in particular those of the European Social } \\
\text { Fund and resources for training available within the } \\
\text { European Agricultural Fund for Rural Development. } \\
\text { Entrepreneurship training must be regarded as an } \\
\text { alternative option for all those who are in school or } \\
\text { engaged in a working or training activity. } \\
\text { - Promote entrepreneurship learning modules for } \\
\text { young people who participate in the Youth Guarantee } \\
\text { national programmes. }\end{array}$ \\
\hline
\end{tabular}

Source: Authors' elaboration data on European Commission (2013), Entrepreneurship 2020 Action Plan - reigniting the entrepreneurial spirit in Europe, http://ec.europa.eu/enterprise/ policies/sme/entrepreneurship-2020/index_en.htm, accessed 7 July 2014.

Besides the programmes included in the compulsory education cycle, the action plan highlights the need of using multiple methods to provide youth with the above knowledge and skills; among them, formal and informal education and volunteering. The action should not just target the new generations but involve a variety of other subjects. In this perspective, a particularly relevant role should be played by partnerships and strategic alliances with other subjects. Entrepreneurial skills, in fact, can be effectively supported and taught only through the collaboration of academic institutions, business incubators, business networks and mobility opportunities within the project. To promote such a culture, in June 2013 the European Commission prepared a guidebook on entrepreneurship education specifically dedicated to educators (EC, 2013). ${ }^{33}$ In addition to developing a number of pan-European initiatives to strengthen its policies, the commission invites all EU member countries to stimulate education to entrepreneurship at all levels, targeting both the young and adults, through the use of structural funds such as FSE and FESR. 
Table 3.4 Main actions recommended by the European Commission: action 2 strengthening the entrepreneurial environment

\begin{tabular}{|c|c|c|}
\hline \multirow{2}{*}{$\begin{array}{l}\text { Scope } \\
\text { Action } 2\end{array}$} & \multicolumn{2}{|c|}{ Actions to be undertaken } \\
\hline & At European level & Calls on member countries to \\
\hline $\begin{array}{l}\text { Strengthen the } \\
\text { environmental conditions } \\
\text { for entrepreneurs; } \\
\text { remove current structural } \\
\text { obstacles; give support in } \\
\text { the crucial phases of the } \\
\text { enterprise life cycle }\end{array}$ & $\begin{array}{l}\text { - Support to the } \\
\text { Enterprise Europe } \\
\text { Network } \\
\text { - Develop integrated } \\
\text { support systems } \\
\text { through capacity } \\
\text { building actions }\end{array}$ & $\begin{array}{l}\text { - Make use of the FEASR to } \\
\text { support start-ups } \\
\text { - Support business clusters, } \\
\text { networks and cooperation } \\
\text { activities }\end{array}$ \\
\hline
\end{tabular}

Source: Authors' elaboration data on European Commission (2013), Entrepreneurship 2020 Action Plan - reigniting the entrepreneurial spirit in Europe, http://ec.europa.eu/enterprise/ policies/sme/entrepreneurship-2020/index_en.htm, data accessed 7 July 2014.

The second action, related to the creation of a business-friendly environment where enterprises may be created and thrive, refers to six areas of action (Table 3.4):

- Access to funding;

- Support to entrepreneurs during the key phases of enterprise life cycle and growth;

- Activate new business opportunities in the digital age;

- Transfers of companies;

- Bankruptcy and second chances for honest entrepreneurs;

- Easing regulatory burdens.

Taking into consideration the second area of intervention, related to support for the crucial phases of the enterprise life cycle, the 2020 action plan highlights that 50 per cent of new enterprises go bust in the first five years of life, often due to the absence of a business-friendly ecosystem that may facilitate their development and growth (EC, 2013, p. 10). ${ }^{34}$

In this regard, business support services could step in and play a role in supporting such companies, which may benefit from their experience. Starting from the assumption that enterprises and entrepreneurs - of all levels and size - need support and advice to deal with new regulations, energy efficiency and recycle requirements, investments for product development, it is absolutely mandatory to promote holistic programmes suitable to combine key elements such as training, tutoring and creation of networks with other similar companies, 
suppliers and potential customers. To this end, the commission intends to strengthen - through direct-management funds - the partnership of the Enterprise Europe network at a pan-European level in order to provide effective assistance, support businesses and facilitate the access to the single market, and also help the single member countries to develop integrated support systems through the implementation of capacity building actions suitable to involve all the interested stakeholders (EC, 2013, p. 12). ${ }^{35}$ At the same time though, the commission calls on all member countries to make full use of the newly introduced support options for start-ups within the FEASR, according to a model aimed at the creation of general systems that may favour professional exchanges between entrepreneurs and visits to farms, also providing support to business clusters, networks and cooperation programmes in the agricultural sector, forestry, food industry and non-agricultural rural enterprises (EC, 2013, p. 14). ${ }^{36}$

The third area of action identified by the commission to promote change in the business culture concerns the cultural perception of entrepreneurs by the community, their role in the society and the involvement of specific groups in the business world, such as women, the elderly, migrants, unemployed individuals and young people, all categories that are poorly represented in the population of entrepreneurs. With regard to specific groups and their role in entrepreneurship, measures aimed at ensuring greater participation and supporting their active role in this area should be based on a support integrated system that, in addition to financial backing, includes also training programmes designed and offered in partnership with education and training providers, schools, youth organisations, business counsellors, financial institutions and all those subjects providing assistance and guidance. With regard to women, who represent a large pool of potential entrepreneurs in Europe, in recent years the commission has implemented a number of measures and programmes to support enterprises created by women and raise awareness (the European network of female entrepreneurship ambassadors) on the necessity of correcting gender imbalances of publicly listed companies.

In line with its previous years, the commission (EC, 2013, p. 14) ) $^{37}$ will create an online platform meant to involve all aspects of tutoring, counselling, training and the creation of business networks for the benefit of female entrepreneurs. Moreover, the commission calls on all the EU member countries to design and implement national strategies to support female entrepreneurship aimed at increasing the number of enterprises led by women and implement conciliation policies (Table 3.5). 
Table 3.5 Main actions recommended by the European Commission: action no. 3 - reigniting the entrepreneurial spirit in Europe through the involvement of specific groups (women)

Actions to be undertaken to support women

\begin{tabular}{ll}
\hline At European level & Calls on member countries to \\
\hline - Strengthen the European network of & - Design and implement national \\
female entrepreneurship ambassadors & strategies to support female \\
- Correct gender imbalances in & entrepreneurship aimed at increasing \\
publicly-listed companies & the number of enterprises led by \\
- Online platform on tutoring, & women \\
counselling, training and creation of & - Support and extend the existing \\
business networks & networks of female entrepreneurship \\
& ambassadors and mentors \\
& - Implement policies promoting a \\
& more balanced relationship between \\
& business and private life (through \\
& FEASR, FSE, FESR) \\
\hline
\end{tabular}

Source: Authors' elaboration data on European Commission (2013), Entrepreneurship 2020 Action Plan - reigniting the entrepreneurial spirit in Europe, http://ec.europa.eu/enterprise/ policies/sme/entrepreneurship-2020/index_en.htm, data accessed 7 July 2014.

As for the elderly, the commission highlights that longer life spans imply also the possibility that some elderly may want to start a business for the first time. It is therefore necessary to design a complete range of services to support this choice. The action of the commission will be focused on the exchange of best practices also through programmes of reciprocal and intergenerational tutoring. The commission calls on the member countries to invite senior entrepreneurs to transfer their know-how and skills to those with no business experience so as to create new integrated groups (Table 3.6).

As for immigrant entrepreneurs, the commission stresses the importance of strengthening their entrepreneurial role and potential. However, as observed by a number of specific studies on the issue (Rath and Swagerman, 2011, p. 40), ${ }^{38}$ enterprises created by immigrants are more likely to fail than others due to lack of information, knowledge and language barriers. According to the commission, therefore, it is necessary to remove all regulatory obstacles and, at the same time, facilitate their access to information, training and business networks, in particular in densely-populated areas by migrants (Table 3.7).

As for the unemployment issue, in particular that affecting young people and aggravated by the current economic crisis, the commission 
Table 3.6 Main actions recommended by the European Commission: action no. 3 - reigniting the entrepreneurial spirit in Europe through the involvement of specific groups (senior entrepreneurs)

Actions to be undertaken to support the elderly

\begin{tabular}{ll}
\hline At European level & Calls on member countries to \\
\hline - Promote exchange of good practices. & - Encourage senior entrepreneurs to \\
- Support through programmes of & transfer their know-how and skills to \\
reciprocal and intergenerational & $\begin{array}{l}\text { young and other entrepreneurs who } \\
\text { do not have business experience so as } \\
\text { assistance. }\end{array}$ \\
& to create integrated groups
\end{tabular}

Source: Authors' elaboration data on European Commission (2013), Entrepreneurship 2020 Action Plan - reigniting the entrepreneurial spirit in Europe, http://ec.europa.eu/enterprise/ policies/sme/entrepreneurship-2020/index_en.htm, data accessed 7 July 2014.

Table 3.7 Main actions recommended by the European Commission: action no. 3 - reigniting the entrepreneurial spirit in Europe through the involvement of specific groups (immigrants)

Actions to be undertaken to support immigrants

\begin{aligned} At European level & Calls on member countries to \\ \hline - & Remove regulatory obstacles to encourage the creation of \\ & enterprises by immigrant entrepreneurs \\ - & Facilitate access to information, training and business \\ & networks \end{aligned}

Source: Authors' elaboration data on European Commission (2013), Entrepreneurship 2020 Action Plan - reigniting the entrepreneurial spirit in Europe, http://ec.europa.eu/enterprise/ policies/sme/entrepreneurship-2020/index_en.htm, accessed 7 July 2014.

highlights the importance of promoting and fostering business support measures in order to encourage the creation of new companies as a solution to escape the vicious circle of unemployment ${ }^{39}$ (Table 3.8). According to the European Commission (EC, 2013, p. 28), ${ }^{40}$ all programmes to support the creation of businesses should indicate information and contacts of business support and counselling services as well as those of tutoring and assistance providers. These services may include the teaching of specific skills and be administered through informal (mentors) or formal methods (courses). This support should be provided in close cooperation with business services, support providers and loan providers. 
Table 3.8 Main actions recommended by the European Commission: action no. 3 - reigniting the entrepreneurial spirit in Europe through the involvement of specific groups (youth)

Actions to be undertaken to support youth

At European level Calls on member countries to

- Link public employment services with business support services and microloans providers

- Design training programmes for entrepreneurship dedicated to unemployed young people and articulate them in distinct phases; start programmes on the labour market to provide financial support to unemployed individuals for the creation of start-ups

- Design and manage entrepreneurship educational programmes dedicated to unemployed individuals to facilitate their reintegration into the labour market as entrepreneurs through the training and education system

Source: Authors' elaboration data on European Commission (2013), Entrepreneurship 2020 Action Plan - reigniting the entrepreneurial spirit in Europe, http://ec.europa.eu/enterprise/ policies/sme/entrepreneurship-2020/index_en.htm, accessed 7 July 2014.

The goal is to help the unemployed to succeed in the transition from unemployment to self-employment, increase the sustainability of their companies and provide specific support to groups that may request additional resources, such as young people or those who cannot be reached through the traditional channels to support businesses.

According to the commission, particular attention should be given to those groups having more potential, such as young people, women and unemployed subjects with professional skills, who can be guided towards self-employment initiatives through forms of tutoring (Table 3.9). For this reason, the commission will start a number of specific programmes (EASI ${ }^{41}$ Progress ${ }^{42}$ the Youth Guarantee ${ }^{43}$ etc.). At the same time, the member countries shall carry on their initiatives at multiple levels (EC, 2013, p. 26). ${ }^{44}$

It should be noted that when the commission refers to specific programmes for entrepreneurship, the business support services (counselling, training and qualification, tutoring and access to credit) should be activated for each phase of the enterprise life cycle (planning, start-up, consolidation and growth). Moreover, the above programmes must necessarily be implemented in partnership with youth organisations, organisations working with women, elderly and immigrants, business consultants and existing financial institutions. 
Table 3.9 Main actions recommended by the European Commission: action no. 3 - reigniting the entrepreneurial spirit in Europe through the involvement of specific groups (unemployed individuals)

Actions to be undertaken to support unemployed individuals

\begin{tabular}{lc}
\hline At European level & Calls on member countries to \\
\hline Start specific programmes & - Link public employment services with business \\
(EASI, Progress, Youth & support services and microloans providers \\
Guarantee, etc.) & Design entrepreneurship training programmes \\
& dedicated to unemployed young people and \\
& articulate them in distinct phases \\
- & Start programmes on the labour market to \\
& provide financial support to unemployed \\
& individuals for the creation of start-ups \\
- & Design and manage entrepreneurship \\
& educational programmes dedicated to \\
& unemployed individuals to facilitate their \\
& reintegration into the labour market as \\
& entrepreneurs through the training and \\
& education system
\end{tabular}

Source: Authors' elaboration data on European Commission (2013), Entrepreneurship 2020 Action Plan - reigniting the entrepreneurial spirit in Europe, http://ec.europa.eu/enterprise/ policies/sme/entrepreneurship-2020/index_en.htm, accessed 7 July 2014.

\subsection{Non-financial services: advantages and operational features}

The term "business development services" (BDS) is used by the European Micro-finance Network (2011 $)^{45}$ to refer to all services needed to support the development of enterprises; within the microcredit system, they are considered additional services to financial products.

Awareness of supporting the provision of financial resources with such services has considerably increased in recent years, in particular in European countries. In fact, the operators realised that microcredit programmes and initiatives can have greater social and economic impact if supported by non-financial services. The interest for these services is justified also by the high number of small and microenterprises operating in Europe as well as by the social and economic background of those willing to start microenterprises. In fact, it is important to keep in mind that the beneficiaries of the microcredit programmes are, generally, disadvantaged individuals who often do not possess the technical skills (managerial, financial, organisational skills, etc.) required to successfully start a microenterprise. As previously seen, business development 
services play a particularly relevant role within the European economic system, which - given its bureaucratic requirements and complex fiscal, regulatory and accounting systems - does not facilitate the birth and survival of microenterprises and self-employment initiatives. With regard to microcredit for businesses (as well as social microcredit), support services may greatly increase the efficacy of any microfinance measure. Microcredit operators, through their support services, can make available to entrepreneurs instruments and skills to support them during the start-up phase of their companies.

To determine which measures fall in the category of non-financial services, we can start from the definition of BDS found in the Guiding Principles for Donor Intervention of the Committee of Donor Agencies for Small Enterprise Development (2001, p. 11): ${ }^{46}$ "BDS are services that improve the performance of the enterprise, its access to markets, and its ability to compete (...). This includes a wide array of business services both strategic and operational (...) aimed at individual enterprises" ${ }^{47}$

While operational services cover those areas needed to run daily operations (information, accounting, regulatory and fiscal management), strategic services regard medium and long-term issues related to the market or competitiveness. These services range from information on markets to training, technical assistance and counselling for entrepreneurs.

A second definition of non-financial services include all those services, provided either formally or informally, that meet the needs of small and medium-sized enterprises other than financial services. They may include: counselling, training, marketing, transportation, connections, information, communication and so on (Gibson, 2001). ${ }^{48}$

BDSs may be divided into three categories, each one with its own relevance within a specific type of enterprises:

1. Client development service: Raising awareness among clients of their basic business or (personal) financial situation. Generally aimed at preventing harmful situations (e.g., overindebtedness, unhealthy environments). Clients are in survival mode and generally not willing to pay for these services.

2. Entrepreneurship development services: Helping individuals to start their own business and raising awareness on entrepreneurship as a career choice, plus basic business skills training. Clients seek to set up a business as a conscious choice, not so much out of necessity.

3. Business Development Service: Supporting existing small-sized businesses to improve their operations, with services ranging from business counselling to technical skills training and linking entrepreneurs to markets. 


\subsubsection{Types of non-financial services}

The data collected in a survey carried out by Fondazione Risorsa Donna for the International Year of the microcredit in Mediterranean countries (Corsi, 2008) ${ }^{49}$ show a positive correlation between the integrated approach to microcredit (provision of loans combined with BDS) and return rate.

Moreover, empirical research has shown that in those countries where it is not possible to compare different approaches to microfinance (Corsi, 2008), ${ }^{50}$ the best results in terms of social and economic women's empowerment seem to be those obtained by MFIs supporting the provision of credit and savings instruments with non-financial services (integrated approach). Integrated programmes lead on average to a positive impact in terms of empowerment for 76 per cent of the women interviewed, while institutions providing just microcredit achieve 62 per cent of positive results; it is, therefore, clear the importance of providing non-financial services in order to positively impact the empowerment.

Non-financial services may be of different types, as we will see below, but they need to meet some criteria: ${ }^{51}$

- They must meet customer needs and requirements as well as new types of businesses and new methods of doing business that are emerging in the market.

- They must be accessible to their customers.

- They must ensure a link between financial and non-financial services, but costs must be kept separate.

- They must be convenient for customers.

Depending on the contexts and the programmes in which they are provided, non-financial services may be structured in different ways and be present in various degrees within the microcredit supply chain. According to the Dictionary of Micro-finance (Santangelo, 2013), ${ }^{52}$ the following are the main non-financial services:

- Guidance to loans;

- Business start-up;

- Business management support;

- Financial education;

- Advice on debt.

Some microcredit providers may include among them also approach and information on their services (Nardone and Costantini, 2011), ${ }^{53}$ 
tutoring, training, coaching and post-credit monitoring. In particular cases, where customers are represented by specific groups, non-financial services may include also linguistic literacy, IT literacy, specific initiatives aimed at women's empowerment and the provision of essential goods (basic health-care services, education for children, food supply).

Approach and information constitute the first qualified and professional contact with the "opportunities" offered by community institutions to enter the labour market and access an articulated microcredit path. Within the approach and information activity, operators act as interfaces between the potential beneficiaries and the physical space where information is disseminated. During this phase, the providers carry out an initial screening process of potential customers.

During the orientation phase (Nardone and Costantini, 2011), ${ }^{54}$ the providers perform an initial assessment of customer needs, requirements and skills. Orientation allows examining issues and resources available to users (both material and immaterial resources) as well as verifying the feasibility of the business projects. The orientation phase includes the possibility of assessing skills and capacities. This is a tool allowing to identify and reconstruct the set of skills and capacities possessed by the customers, enhancing also the mechanisms that govern and support their acquisition. The focus is put also on the so-called implicit skills (those skills and capacities acquired through actual experiences but not managed through structural communication flows) so as to make them spendable on the labour market.

The skills assessment phase is a person-centred process: potential entrepreneurs are required to put in place their own projects and, through the evaluation, make the necessary adjustments in their future choices. It consists of individual meetings where interests, motivations, skills and potential are examined in order to identify a business development plan. At the same time, a loan orientation service is provided (Santangelo, 2013, p. 761), ${ }^{55}$ which consists in identifying the most appropriate loans for the borrowers in terms of amount granted, return times and type of financial product.

During the orientation phase, a further screening of the potential customers is performed. The orientation, in fact, can be used to direct users towards other processes or types of loans that better suit their profiles, as emerged from the interviews. Business start-up services include tutoring, pre-assessment and training.

In the tutoring service, the final recipients are assisted in the development of their business projects by the non-financial services providers, which offer an initial counselling on opportunities and criticalities 
detected. Tutors act as facilitators for the fulfilment of administrative and fiscal obligations, preparation of business plans, assistance for the preparation of documents, document transmission and accompanying service to the banks or microcredit providers.

The pre-assessment service provides for an analysis of:

- the business idea;

- skills (including potential skills) and attitude of the potential recipients;

- the appropriateness of the requests;

- customer reliability.

Training activities focus especially on financial and management issues and their goal is to improve the entrepreneurs' skills on economic-operational-financial issues. This phase includes those training activities that may involve the preparation of business plans; business operational and management issues; budget and accounting; short language courses for immigrants; IT literacy sessions for disadvantaged groups.

The courses may consist of multiple levels of specialisation but are essential for all those who approach the entrepreneurial activity for the first time. In the phase following the start-up, entrepreneurs may be assisted through the provision of specific services, such as mentoring, technical assistance, training, tutoring and financial monitoring. Mentoring consists in a path where new entrepreneurs are coached by senior entrepreneurs, with the aim of transferring experiences made by the latter in similar or identical business sectors. This activity is even more effective if the mentor is a former microcredit recipient. To strengthen the skills of the new entrepreneurs and support them in the most delicate phase of their enterprises - generally the first three years it is necessary to envisage the provision of special technical support services to be offered at offices/branches (on request) on business operating management areas, such as tax and fiscal assistance, marketing, IT, access to funding sources.

Training in the phase following the start-up covers mainly financial and management issues, aimed at improving the entrepreneurs' economic-operating-financial skills. Here, possible areas of teaching are as follows: business development services, commercial marketing, financial literacy, financial and accounting management. Following the disbursement of the loans and the start-up phase of the companies, endusers are equally assisted, for a period of at least three years, through the tutoring activity. The aim here is to detect any difficulties and problems 
Table 3.10 Non-financial services in the different phases of the enterprise life cycle

\begin{tabular}{|c|c|c|}
\hline Enterprise life-cycle & $\begin{array}{l}\text { Non-financial } \\
\text { services }\end{array}$ & Definition \\
\hline Concept & $\begin{array}{l}\text { Approach and } \\
\text { information }\end{array}$ & $\begin{array}{l}\text { Communication to the target clientele } \\
\text { on local opportunities to enter the } \\
\text { labour market }\end{array}$ \\
\hline Concept & Orientation & $\begin{array}{l}\text { Initial assessment of skills and } \\
\text { capacities } \\
\text { Loan orientation }\end{array}$ \\
\hline Design & Tutoring & $\begin{array}{l}\text { End-users are assisted in the } \\
\text { development of their business ideas } \\
\text { through initial counselling on the } \\
\text { opportunities and difficulties detected }\end{array}$ \\
\hline Design & Pre-assessment & $\begin{array}{l}\text { Analysis of business ideas, skills } \\
\text { (including potential skills) and } \\
\text { attitude of the potential end-users } \\
\text { Analysis of appropriateness of } \\
\text { the requests and reliability of the } \\
\text { applicants }\end{array}$ \\
\hline Design & Training & $\begin{array}{l}\text { Acquisition of economic-operational- } \\
\text { financial skills } \\
\text { Preparation of business plan } \\
\text { Financial, linguistic, IT literacy } \\
\text { Operating and management aspects of } \\
\text { the microenterprises }\end{array}$ \\
\hline Start-up & Mentoring & $\begin{array}{l}\text { Mentoring by "senior" entrepreneurs } \\
\text { to transfer experiences }\end{array}$ \\
\hline $\begin{array}{l}\text { Start up } \\
\text { (in the first three years } \\
\text { of the enterprise) }\end{array}$ & $\begin{array}{l}\text { Technical } \\
\text { support }\end{array}$ & $\begin{array}{l}\text { Special support for all matters related } \\
\text { to operational management }\end{array}$ \\
\hline Start-up & Training & $\begin{array}{l}\text { Aimed at improving financial and } \\
\text { management skills }\end{array}$ \\
\hline $\begin{array}{l}\text { Start-up } \\
\text { (in the first three years } \\
\text { of the enterprise) }\end{array}$ & Tutoring & $\begin{array}{l}\text { Aimed at detecting financial and } \\
\text { management issues affecting the } \\
\text { enterprises }\end{array}$ \\
\hline $\begin{array}{l}\text { Start up } \\
\text { (in the first five years } \\
\text { of the enterprise) }\end{array}$ & $\begin{array}{l}\text { Financial } \\
\text { monitoring }\end{array}$ & Verification of loan repayment \\
\hline Start-up & Networking & $\begin{array}{l}\text { Creation of the cultural and operating } \\
\text { context to facilitate the survival of } \\
\text { enterprises through local networks }\end{array}$ \\
\hline
\end{tabular}

Source: Authors' elaboration. 
that may arise in due course and affect loan repayments and the survival of companies. Tutoring takes place through periodic visits or telephone interviews to the beneficiaries. Finally, financial monitoring ensures timely verification of the loan repayments for their whole duration. This activity must be performed periodically (once a month) and carried out in collaboration with the lenders (banks).

Networking represents a non-financial service transversal to the stages preceding and following the disbursement of the loans. It consists in the creation of local networks of public institutions, training providers, schools, businesses, chambers of commerce, employers' organisations, microfinance institutions, business service centres, operators, and the like. The objective here is to create a healthy cultural and operational context needed to promote entrepreneurship and facilitate the survival of businesses.

\subsubsection{Who funds the non-financial services?}

We have mentioned the importance of the BDS as essential instruments for start-ups. However, the main problem faced by microfinance institutions and those microcredit providers is to identify who can fund and support their operations. Such services, in fact, have a cost in terms of human and financial resources.

A survey (Lämmermann and Ribbink, 2011) ${ }^{56}$ carried out by the European Microfinance Network ${ }^{57}$ at a European level showed different models (Lobbezoo, 2012) ${ }^{58}$ of provision of financial services and financial support in Europe (Table 3.11). As previously seen, the European Commission invited all member countries to make use of the financial resources provided by the structural funds to support these services (EC, 2013), ${ }^{59}$ in particular the European Social Fund.

\subsection{Partnerships in delivery financial and BDSS services to the microcredit beneficiaries in Romania}

Microfinance activities specifically targeting microentrepreneurial activities started in Romania around 20 years ago (1992-1995), when the first international microfinance organisations launched entrepreneurship development and microfinance projects in Romania. At the end of the project phase, the microfinance activities were transferred to the NGOs/ foundations established to ensure continuation and sustainability of the interventions. During 2004-2009, due to the changes in the legal framework for microcredit provision, the NGOs registered as non-bank 


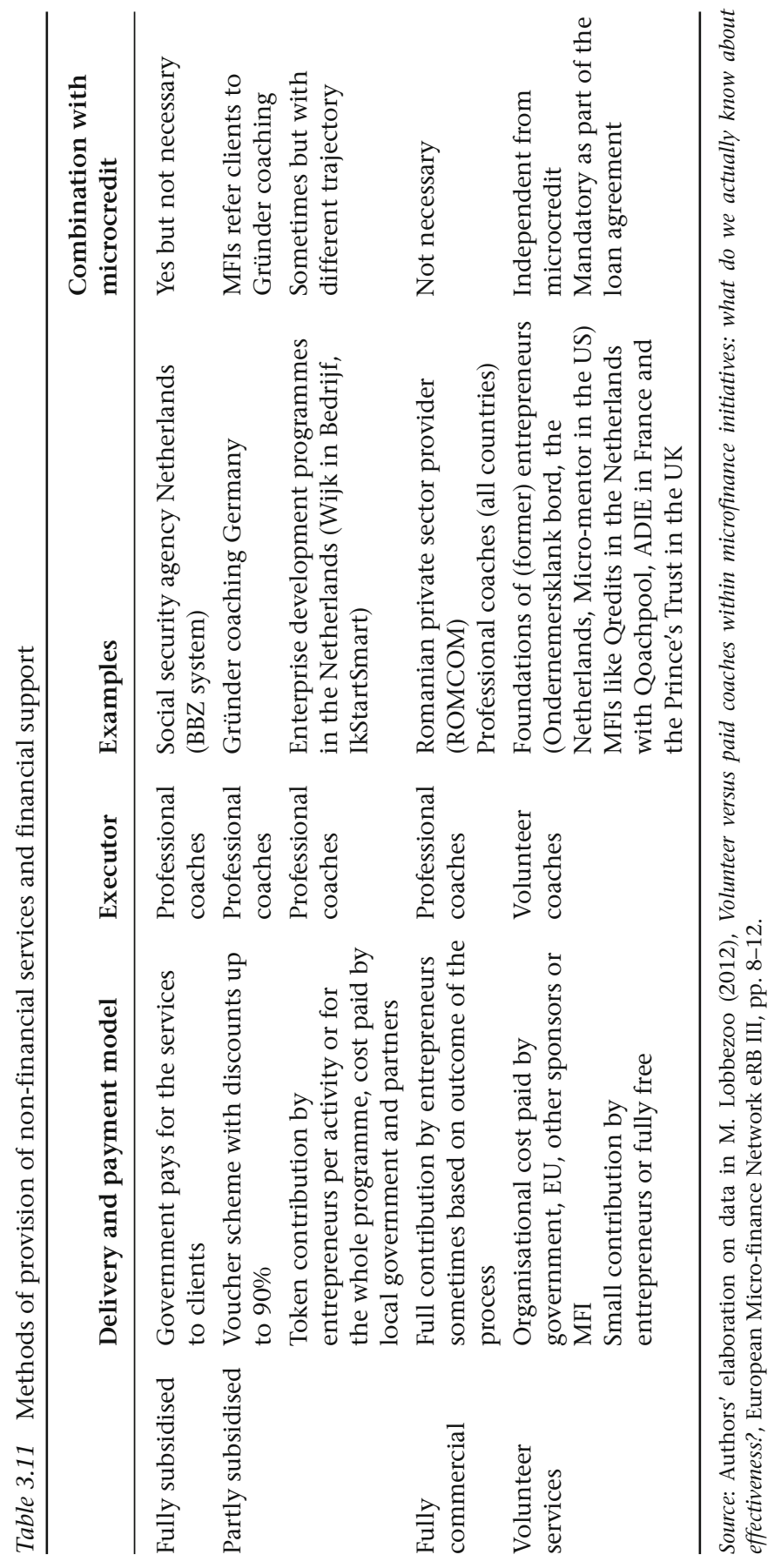


financial institutions (NBFIs) and transferred their financial portfolio to the newly established entities, becoming majority owners of the NBFIs.

According to the EMN's MF survey 2010-2011, the Romanian microfinance sector ranks fifth in the European Union in terms of value and number of business microloans disbursed, ${ }^{60}$ a position maintained during 2012-2013. The Romanian MFIs were among the most active participants and beneficiaries of the EU-funded financial instruments Progress Microfinance and JASMINE-TA program during 2009-2013 and subscribed to comply with the clauses of the European Code of Good Conduct of Microcredit Provision (EUCoGC).

A specific approach to deliver BDS to the microcredit clients is developed by the Romanian MFIs mainly due to a specific legal framework requirement; therefore the only activity authorised to be developed by the non-bank financial institutions (NBFIs) is financial activity. In the current legal context, the BDSS are provided by NBFIs' partners, consulting and training firms and/or NGOs specialising in entrepreneurship development or the foundations which are the major shareholders of the NBFIs.

\subsubsection{Case study 1. Partnership in the delivery of integrated financial and business development services: FAER NBFI and FAER Foundation}

FAER Romania ${ }^{61}$ is currently one of the medium-size MFIs specialising in financial and non-financial services for rural agribusiness. It consists of FAER IFN (NBFI), provider of microcredits, and FAER Foundation, which provides BDSS and other non-financial services, mainly community development services, to the FAER NBFI's microcredit clients and to the communities where its clients are located.

The financial resources needed to provide BDSS and other non-financial services are the profit of the financial operations, donations and EU structural funds for entrepreneurship and human resource development as additional funds that co-finance the services provided to the FAER NBFI's microcredit clients and to the potential clients within the communities where the MFI is operating.

The project Entrepreneurship from Ideas to Success, implemented during 2019-2011, with financial support from EC structural funds and the Romanian government, has had as overall objective to encourage sustainable development by promoting entrepreneurship among small businesses and potential entrepreneurs, including young people who want to start a business in small Romanian towns. The project activities were designed to facilitate the entrepreneurs' active role in community 
life, helping them to initiate, develop and better manage their microbusiness and individual enterprises (sole entrepreneurs, legally registered professionals, family business, registered small farmers, etc.) contributing to jobs creation, job maintenance and self-employment.

The project contributed to the objectives of Romania's human resource development strategy at three levels: entrepreneurship promotion, enhancement of training and business performance management culture through a network of four business information and advisory centres, advice and assistance and an e-learning platform to facilitate the continuity and multiplication of project's results.

During the two years of project implementation, according to the project's report, ${ }^{62}$ the following results were achieved:

- 1,560 participants (ca 700 women) attended the information sessions, business courses, business development advice sessions and exchange visits organised within the project;

- 32 trainers/business advisors were trained and certified;

- a network of four business information and advisory centres to support entrepreneurship was created and 100 MSMEs assisted and received advisory services;

- 50 start-ups were assisted to register their legal operational entity;

- 50 investment and development project proposals submitted by the targeted beneficiaries were funded.

\subsubsection{Case study 2. Partnership in the delivery of integrated financial and BDS services: RoCredit-NBFI and Eurom business consulting company}

In order to fulfil its mission and enhance the impact of financial services, the BDS services provided to its clients are delivered in partnership with specialised business training and consulting providers. The BDS services - for example, financial education and business training and consulting - are delivered to RoCredit's beneficiaries by RoCredit loan officers and business consultants/trainers of Eurom Consultancy and Studies SRL. RoCredit microfinance institution was founded in January 2007 by Romanian investors as an NBFI. The funders' initial contribution was the start-up capital of the MFI. In March 2007 RoCredit was certified and licensed by the Romanian Central Bank as a non-bank financial institution. Currently RoCredit has a gross loan portfolio of $€ 15$ million and 1,300 active clients served through a network of 11 offices located in Transylvania and Muntenia regions. It is currently 
the third largest MFI in Romania in terms of GLP, registered in the special registry (for large NBFI) of NBR. The targeted beneficiaries of RoCredit are sole traders, self-employed and micro- and small enterprises which carry out their activity in urban or rural areas, not bankable business in the development phase, having as main field of activity production, services, trade, farmers owning a small semi-subsistence farm with low income. RoCredit offers a large range of financial products to the targeted beneficiaries, from short-term working capital credit lines or credit lines secured by promissory note to medium-term working capital credits and investment credits, guarantee and financial products designed to co-finance investments of the EU structural funds beneficiaries. Eurom Consultancy and Studies SRL ${ }^{63}$ was established in 2002 as a private consulting company with a major portfolio of clients and assignments in the area of SMEs access to finance and microfinance, including:

- business consulting to SMEs and entrepreneurs looking for finance and financial institutions with social inclusion mission: MFIs, credit unions;

- training programs for MSMEs and potential entrepreneurs on various topics from financial literature to investment project's appraisal;

- research and studies, technical assistance to financial services providers: MFIs performance assessment; feasibility studies and TA for financial instruments; revolving microcredit schemes; guarantee funds for SMEs, equity investments in SMEs; grant scheme for local/ regional development and rural development.

Eurom was a member of the European Microfinance Network's board of directors as vice-president for central and eastern Europe between 2006 and 2010, coordinated and led the EMN's Legal and Regulatory Working Group and during 2007-2013 partnered EMN in the implementation of JASMINE help desk and JASMINE workshops.

Eurom contributed, along other key stakeholders of the MF sector in Europe, to the development of the European Code of Good Conduct for Microcredit Provision. ${ }^{64}$

\section{Brief description of the BDS services}

"Client first" is an innovative initiative that combines financial services: microcredits for investments in productive asset and equipment acquisition with tailored business development support services (BDSS) for clients and potential clients: microenterprises, farmers, start-up entrepreneurs located in rural areas and small towns of Romania. 
Context: The microenterprises represent 89.3 per cent of the Romanian private sector in the years 2009-2012 in the context of the financial crisis, the tendency of microenterprises and sole traders of reducing the investments in productive assets, aimed to develop production/services base, due to lack of appropriate resources is preventing their development, growth and graduation into small and medium enterprises.

According to the RoCredit's 2010-2011 annual portfolio report, 95 per cent of the loans are extended to microenterprises. Analysing the percentage of microcredits used to purchase productive assets or for investments in improving the productive premises, it was observed the high rate of applications rejected (35 per cent), compared to the working capital loan applications.

Therefore, RoCredit in partnership with Eurom initiated in 2012 a pilot project aimed to increase the microcredit portfolio for productive assets acquisition, improve its quality and to diminish the applications' rejection rate.

\section{First phase}

The BDSS pilot project consists in organising "project clinics" (workshops) for RoCredit clients and potential clients for the assessment of the feasibility of the client's investment proposal using an financial analysis and forecasting tool developed as MS Excel application; following positive result of the proposal's appraisal, the provision of the loan was made with characteristics that match the investment specifics - for example, loan period, grace period. The monitoring of the client's investment proposal implementation and assessment of the beneficiary performance during the loan period was performed by the RoCredit loan officers.

So far funded from its own resources and benefiting from the program Entrepreneurship from Idea to Success, an EU-funded project, 11 clinics were organised in Pitesti and Bistrita RoCredit's branches (2 of 14 branches of RoCredit) for 58 entrepreneurs. A project clinic consists of a one-hour presentation of the investment's assessment methodology, followed by one-to-one working sessions. The beneficiary and the Eurom consultant are assessing and computing the input data of the investment, calculation of the investment project indicators for up to five years and interpretation of the investment's indicators, forecasted $\mathrm{P} \& \mathrm{~L}$ and cash flow.

Based on the analysis the client may decide on $n$ investment's opportunity, the size, the implementation schedule of the investment, and it will get guidance from RoCredit's credit officers in the selection of the appropriate financial product from RoCredit offer that will fit to 
the investment characteristics and potential for reimbursement; for example, value of the loan, loan period, grace period (for interest), repayment schedule. The project's first-phase results were positive, the investment loan portfolio in the two branches increased by 30 per cent, the investment application rejection rate decreased by 50 per cent and the quality of the portfolio improved.

\section{Second phase}

In October 2012, the training for the RoCredit's credit officers in assessment of investment project's feasibility and utilisation of the assessment tool was introduced in the curriculum of the JASMINE TA program and delivered to all RoCredit's credit officers, branch managers and risk management department staff. The investment indicators NPV (net present value) and IRR (internal rate of return) were introduced in the loan risk-assessment procedure.

\section{Third phase (ongoing)}

Project clinics are organised in each Rocredit branch with the assistance of Eurom consultants; impact indicators are collected, analysed and reported each quarter in order to improve the efficiency of the business development services delivery and its effectiveness on client performance.

In this perspective, it's important to underline the innovative opendoor approach of the BDSS in partnership. Clients and potential clients are invited to participate to the event organised in the brunch office special organised and equipped to host up to ten participants. The business development services are not extended exclusively to the RoCredit's clients but to potential clients as well: start-ups, young entrepreneurs, potential entrepreneurs currently unemployed, minorities, and so on. It is not exclusively a marketing tool to promote RoCredit's financial offer but mainly a customised business service aimed to assist the client in the development of its business.

The innovative methodology and assessment tools used are described below:

- Presentation: The project's assessment tool is presented by the consultant or credit officer using a PowerPoint presentation and the video projector; handouts of the presentation are available. After the project's assessment tool presentation by the consultant or credit officer, the beneficiary becomes the main "actor" of the show. 
- Financial analysis and forecasting tool, developed as MS Excel application, is designed based on UNIDO's SME's investment projects' feasibility assessment methodology, in constant prices (inflation influence is ignored).

- Compilation of analysis's input data is based on the info provided by the beneficiary therefore confidentiality of beneficiary data and info is ensured by signing and confidentiality agreement. The input data consist of

- value and items of the investment and their depreciation period;

- products/services resulted after the project implementation: quantity and current unit price; estimated production capacity utilisation within the analysis period (five years);

- costs related to the production/services: labour costs, raw materials, administrative costs, marketing, taxes and so on;

- working capital needs, based on the characteristics of the products/ services;

- financial inputs: beneficiary's own financial resources, loan, grant, equity investment.

- Transfer of the input data: After compilation of the input data, the transfer to the tool is provided by the consultant or the credit officer.

- Outputs from the forecasting tool are obtained instantaneously:

- forecasted investment project's balance sheet, P\&L and cash flow;

- forecasted investment project's indicators: profitability indicators and break-even, liquidity and coverage indicators and investment indicators NPV and IRR;

- graphical representation of the main indicators.

- Interpretation and fallow up: At the end of the session the client receives not only the know-how to interpret the investment performance indicators as its sensitivity towards market potential changes during the investment phase but the printed forecasts of the project's balance sheet, P\&L and cash flow of its own investment project idea, as well as clear guidance to selecting a suitable financial product.

What differentiates the "client first" BDSS services from the current consulting services provided by RoCredit to its clients is the focus on clients' and potential clients' specific and long-term needs, the capacity building component in beneficiary's self-assessment of the investment project feasibility, the improvement of the internal risk appraisal techniques for loan applications with an investment component. 
What differentiates the "client first" BDSS services from other BDSS services in the market is the establishment on a solid base of long-term partnership in development, one based on trust and fairness between the BDSS and financial services providers and the beneficiaries.

\section{Sustainability}

At the EU level, the eastern European MFIs are considered and labelled as more commercially than socially oriented. The efforts the main Romania MFIs, RoCredit included, are making to chance the "commercial label" consist in targeting and serving the non-bankable entrepreneurs, increasing transparency, providing innovative business development services and support to the clients, and fully implementing the European Code of Good Conduct for microcredit provision. Within the last three years 55 per cent of the annual profit was reinvested by RoCredit in development and outreach co-financed by EU-funded programs and/or through partnerships with BDSS providers, investment in training and development of staff, new products and services, MIS and in the market development ensured the continuous growth of the organisation.

\section{Sustainability of the "client first" initiative}

In the initial stage, due to the positive impact, the board of administration decided the "client first" BDSS to be further developed within the partnership agreement signed in January 2013 with Eurom.

In 2013-2014 the estimated number of "client first" clinics organised is 40 in all branches located in four Romanian economic regions with an estimated 300 participants, entrepreneurs and potential entrepreneurs, 20 per cent of RoCredit active clients, at least 200 projects assisted to be financed and implemented successfully.

The "client first" methodology and approach will be extended to all RoCredit current financial products for microentrepreneurs; the internal loan application risk-assessment procedures will include the investment indicators along with the liquidity and financial coverage indicators. Impact indicators and case studies of successfully implemented investment/development projects alongside the "client first" clinics are planned to be the main marketing instruments of the MFI within the following years. Subject of availability of resources the "client first" investment project feasibility assessment tool will be further develop in an online assessment tool, posted on the RoCredit website, available for all clients and potential clients of the MFI. 


\section{Impact}

The aim of the "client first" initiative is to redesign the BDSS, having in mind that the client-focused mission of the MFIs has to be translated and implemented not only through the financial products designed to meet the client's needs but through non-financial services as well; the client's interest and benefit should become the first priority; the MFI benefit should follow in the second position. Therefore impact indicators, qualitative and quantitative, financial and non-financial, were developed to assess the efficiency and effectiveness of the initiative. The pilot phase's impact indicators' outputs and results/outcomes obtained and targets for 2014 are in Table 3.12.

The "client first" initiative, as presented, does not address only the issues specific to the MFI - for example, high rejection rate of loan applications for investment, credit officers' lack of knowledge in assessing the feasibility of the investment projects, PAR and so on. It addresses a general issue of the MFIs' targeted beneficiaries: start-ups and microenterprises, potential entrepreneurs, lack of knowledge, clear guidance and appropriate financial resources to implement their business idea or development plan. The "open-door approach", the "innovative methodology" partnership with a business consulting firm, specialising in services related to SMEs access to finance, the targeted beneficiaries; current and potential clients, and never the less, the cost effectiveness of the initiative recommend it to be adopted by the other Romanian MFIs in the first stage. Transformed in an online investment project feasibility assessment tool, assisted on line by the consultants and the credit officers of the MFIs, will make it more accessible, less time and resources consuming and therefore more efficient. Adapted to the specifics of each country legal fiscal regime for entrepreneurship activities and micro enterprises, the tool can be replicated in the neighbouring Eastern European countries, where the MFIs' targeted beneficiaries are facing the same growth difficulties, as well as in other countries where the MFIs are targeting the start-ups and non-bankable clients. The positive results of the pilot phase recommended the initiative to be expanded, the lessons that will be learned from this challenging experience will be subject to case studies and presentations to the microfinance events organised in Romania and in Europe, with the support of the EMN working groups: IT and Social impact, the Client first initiative will be promoted among the European MF providers. 


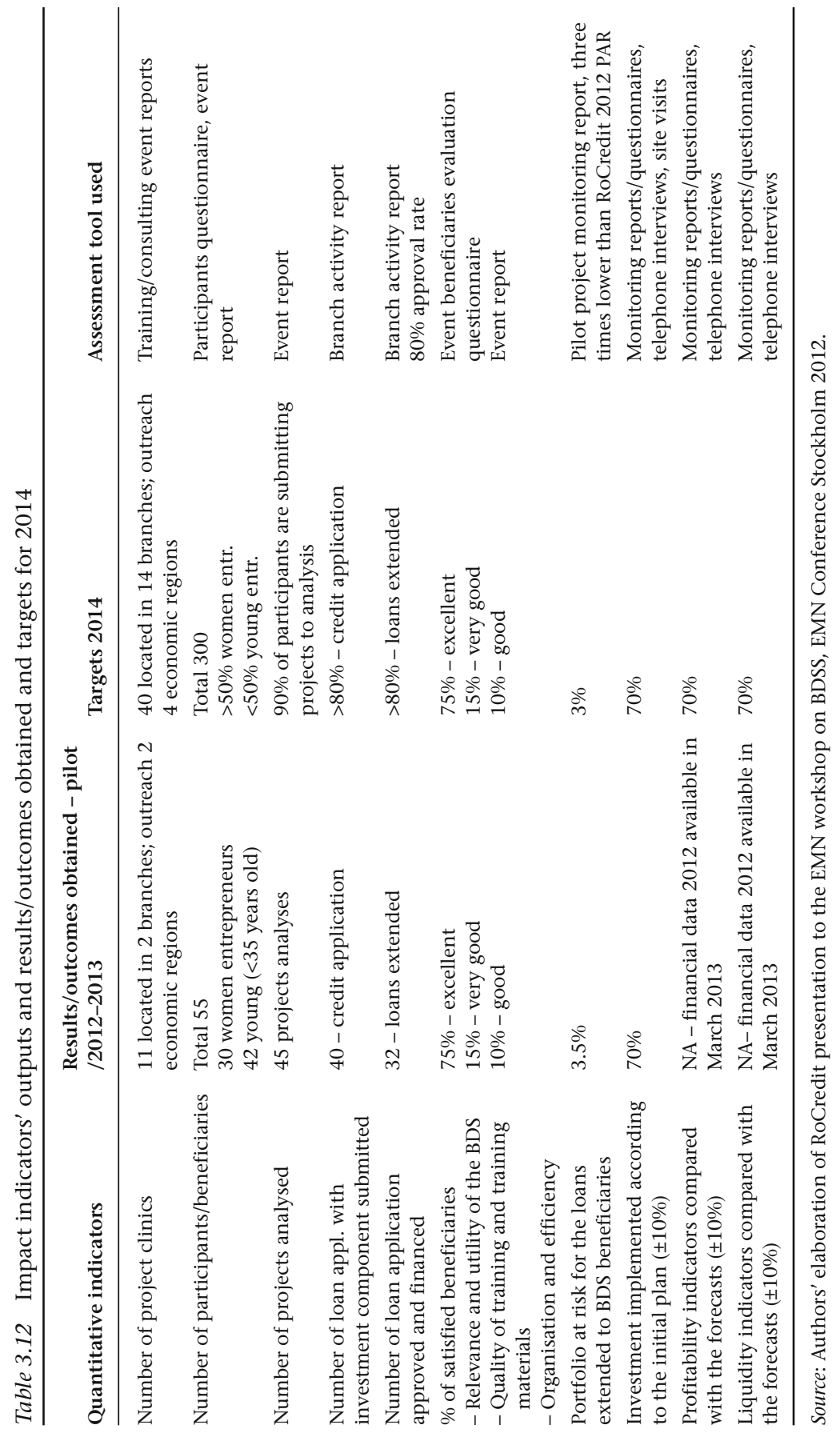




\section{Notes}

1. Although this chapter was prepared jointly by the authors, $\S 3.1$ was written by Giovanni Nicola Pes, $\S 3.2$ by Stefanie Lämmermann, $\S \S 3.3$ and 3.4 by Andrea Nardone, §§3.5, 3.5.1 and 3.5.2 by Maria Claudia Costantini and §3.6 by Maria Doiciu.

2. European Commission (2013), 2013 SMEs' access to finance survey, analytical report, 14 November, pp. $6 \mathrm{ff}$.

3. See esp. "Europe 20" and "Small Business Act".

4. COM 2020 of 3 March 2010: "Europe 2020, a strategy for smart, sustainable and inclusive growth".

5. In 2011, the European Central Bank (ECB) started to adopt a number of specific measures that are partly reducing the risk that a reduction of bank assets might result in a direct contraction of the economic activity. Lately, the decisions adopted by the ECB Governing Council in June 2014 - which established, among other things, that, starting September 2014, the amount of funds granted to each bank shall be proportional to the volume of loans that the bank itself granted to the economic system - should further loose monetary restrictions and support the provision of credit.

6. Survey jointly carried out by the European Commission and the European Central Bank by administering a specific questionnaire to the EU-28 SMEs, in the period August-October 2013. The survey results are indicated in "SMEs Access to Finance survey, Analytical Report", 14 November 2013.

7. The pre-coded list included the following potential problems: finding customers, access to credit, availability of experienced and qualified personnel, regulation, competition, cost of production or labour, other.

8. This survey, which terminated on 8 April 2014, was participated also by eight of the main bank groups in Italy. The results for our country can be found on the website: www.bancaditalia.it, while those for the Euro area at: www.ecb.int.

9. EC elaboration of ECB survey results on Amadeus and EFIGE data, in "European Competitiveness Report 2014 - Helping firms grow", Commission Staff Working Document SWD (2014) 6319 final, pp. 15ff.

10. See EU regulation no. 1304 of the European Parliament and Council of 17 December 2013, on the European Social Fund, art. 2, paragraph 1.

11. See EU regulation no. 1304 of the European Parliament and Council of 17 December 2013, on the European Social Fund, art. 2, paragraph 3.

12. See EU regulation no. 1304 of the European Parliament and Council of 17 December 2013, on the European Social Fund, art. 15.

13. Art. 37 of the aforementioned regulation states that "Where financial instruments support financing to enterprises, including SMEs, such support shall target the establishment of new enterprises, early-stage capital, that is, seed capital and start-up capital, expansion capital and capital for the strengthening of the general activities of an enterprise, or the realisation of new projects, penetration of new markets or new developments by existing enterprises, without prejudice to applicable Union State aid rules, and in accordance with the Fund-specific rules. Such support may include investment in both tangible and intangible assets as well as working capital within the limits of applicable Union State aid rules and with a view to stimulating the private sector as a supplier of funding to enterprises. It may also include 
the costs of transfer of proprietary rights in enterprises provided that such transfers take place between independent investors".

14. http://www.goldrausch-ev.de/.

15. http://www.wasistgarage.de/.

16. http://www.microlending-news.de/artikel/enterprise.htm.

17. http://www.exzet.de/index.html.

18. http://www.kiz.de/.

19. http://www.mikrofinanz.net/.

20. European Commission - DG Enterprise and Industry (2006), Management capacity building - final report of the expert group, p. 29, http://ec.europa.eu/ enterprise/policies/sme/files/support_measures/mcb/mcb_en.pdf, accessed 7 July 2014.

21. European Commission (2007), Communication from the Commission to the Council, the European Parliament, the European Economic and Social Committee and the Committee of the Regions, A European initiative for the development of microcredit in support of growth and employment, http:// eur-lex.europa.eu/LexUriServ/LexUriServ.do?uri=COM:2007:0708:FIN:en: PDF, accessed 7 July 2014.

22. European Commission (2007), Communication from the Commission to the Council, the European Parliament, the European Economic and Social Committee and the Committee of the Regions, A European initiative for the development of microcredit in support of growth and employment, p. 9, http:// eur-lex.europa.eu/LexUriServ/LexUriServ.do?uri=COM:2007:0708:FIN: en:PDF, accessed 7 July 2014.

23. European Commission (2007), Communication from the Commission to the Council, the European Parliament, the European Economic and Social Committee and the Committee of the Regions, A European initiative for the development of microcredit in support of growth and employment, p. 8, http:// eur-lex.europa.eu/LexUriServ/LexUriServ.do?uri=COM:2007:0708:FIN: en:PDF, accessed 7 July 2014.

24. European Commission (2007), Communication from the Commission to the Council, the European Parliament, the European Economic and Social Committee and the Committee of the Regions, A European initiative for the development of microcredit in support of growth and employment, p. 8, 27, http://eur-lex.europa.eu/LexUriServ/LexUriServ.do?uri=COM:2007: 0708:FIN:en:PDF, accessed 7 July 2014.

25. European Commission (2008), Think small first. A "small business act" for Europe, http://ec.europa.eu/enterprise/policies/sme/documents/sba/index_ en.htm, accessed 7 July 2014.

26. European Commission (2008), Think small first. A "small business act" for Europe, p. 5, http://ec.europa.eu/enterprise/policies/sme/documents/sba/ index_en.htm, accessed 7 July 2014.

27. European Commission (2008), Think small first. A "small business act" for Europe, p. 6, http://ec.europa.eu/enterprise/policies/sme/documents/sba/ index_en.htm, accessed 7 July 2014.

28. Ibid.

29. European Commission (2013), Entrepreneurship 2020 Action Plan - reigniting the entrepreneurial spirit in Europe, p. 4, http://ec.europa.eu/enterprise/policies/sme/entrepreneurship-2020/index_en.htm, accessed 7 July 2014. 
30. Ibid.

31. European Parliament, European Council (2006), Recommendation of the European Parliament and of the Council of 18 December 2006 on key competences for lifelong learning, Official Journal of the European Union, L394/10, http:// eur-lex.europa.eu/LexUriServ/LexUriServ.do?uri= OJ:L:2006:394: 0010:0018: en: PDF. accessed 7 July 2014.

32. Jenner C. (2012), Business and education: powerful social innovation partners, Stanford Social Innovation Review, August, p. 27; European Commission (2012), Rethinking Education: Investing in skills for better socio-economic outcomes, http://ec.europa.eu/digital-agenda/en/news/communication-rethinkingeducation, accessed 7 July 2014; OECD, European Union (2012), Policy brief on youth entrepreneurs, Brussels.

33. European Commission - DG Enterprise and Industry (2013). Entrepreneurship education: a guide for educators, http://ec.europa.eu/enterprise/policies/sme/ promoting-entrepreneurship/files/education/entredu-manual-fv_en.pdf, accessed 7 July 2014.

34. European Commission (2013), Entrepreneurship 2020 Action Plan - reigniting the entrepreneurial spirit in Europe, COM (2012) 795 final, p. 10, http://ec.europa. eu/enterprise/policies/sme/entrepreneurship-2020/index_en.htm, accessed 7 July 2014.

35. European Commission (2013), Entrepreneurship 2020 Action Plan - Reigniting the entrepreneurial spirit in Europe, COM (2012) 795 final, p. 12, http://eurlex. europa.eu/LexUriServ/LexUriServ.do?uri=COM:2012:0795:FIN:IT:PDF, accessed 7 July 2014.

36. European Commission (2013), Entrepreneurship 2020 Action Plan - Reigniting the entrepreneurial spirit in Europe, COM (2012) 795 final, p. 14, http://eurlex. europa.eu/LexUriServ/LexUriServ.do?uri=COM:2012:0795:FIN:IT:PDF, accessed 7 July 2014.

37. Ibid.

38. Rath, J. and Swagerman A. (2011), Promoting ethnic entrepreneurship in European cities, European Foundation for the Improvement of Living and Working Conditions, Publications Office of the European Union, Luxembourg, p. 40. http://www.eurofound.europa.eu/pubdocs/2011/38/en/2/EF1138EN.pdf, accessed 7 July 2014.

39. As indicated in the Policy Brief on Youth Entrepreneurship in Europe (EC, 2012), there are very few programmes to support the creation of businesses specifically targeting unemployed youth.

40. European Commission (2013), Entrepreneurship 2020 Action Plan - reigniting the entrepreneurial spirit in Europe, p. 28, http://ec.europa.eu/enterprise/ policies/sme/entrepreneurship-2020 /index_en.htm, accessed 7 July 2014.

41. With regard to social solidarity, the European Parliament and Council reached a political agreement on the EU programme for employment and social innovation that goes under the name of EASI. Along with the European Social Fund, the Fund for the European Aid for the most Deprived and the European Globalisation Adjustment Fund, EASI constitutes the fourth pillar of the EU initiative to promote employment and social inclusion within the broader Action 2014-2020. The EASI will provide support to the member countries to design and implement social and employment reforms, both at a national and regional and local level through a number of policies meant 
to coordinate, identify, analyse and share the best practices. EASI integrates and extends the coverage of three existing programmes:

- Progress (Programme for Employment and Social Solidarity);

- $\quad$ EURES (European Employment Services);

- European Progress Micro-finance Facility.

In the latter, the combination of microfinance and social entrepreneurship will be oriented towards the facilitation to credit access for entrepreneurs, especially those who struggle to reach the traditional credit market, and for social enterprises. The support to the development of social enterprises is the true innovative aspect of this axis, compared to the current Progress of microfinanced that kick-started in 2010, to which is added also a greater support to microcredit providers through the funds granted to the capacity building actions promoted by these subjects. http://ec.europa.eu/social/ main.jsp?catId=1081, accessed 7 July 2014.

42. http://ec.europa.eu/social/main.jsp?catId=327.

43. http://www.youth-guarantee.eu/, accessed 7 July 2014.

44. European Commission (2013), Entrepreneurship 2020 Action Plan - reigniting the entrepreneurial spirit in Europe, p. 26, http://ec.europa.eu/enterprise/policies/sme/entrepreneurship-2020 /index_en.htm, accessed 7 July 2014.

45. Lämmermann S. and Ribbink G. (2011), Micro-finance and business. Development services in Europe. What can we learn from the South?, European Micro-finance Network.

46. Committee of Donor Agencies for Small Enterprise Development (2001), Business development services for small enterprises. Guiding principles for donor intervention, February, Washington, Donor Committee, p. 11.

47. Committee of Donor Agencies for Small Enterprise Development (2001), Business development services for small enterprises. Guiding principles for donor intervention, February, Washington, Donor Committee, p. 11.

48. Gibson A. (2001), Principles of good practice in business development services, in Levitsky and Mikkelsen, Micro and small enterprises in Latin America, London, IADB, ITDG.

49. Corsi M. (2008), Women and micro-finance. A look at the Mediterranean countries, Rome, Aracne. This study covered microfinance institutions from the following countries: Albania, Bosnia and Herzegovina, Croatia, Egypt, France, Italy, Jordan, Kosovo, Lebanon, Morocco, Spain and Tunisia.

50. The literature refers to integrated and minimalist approaches to define different models of microfinance existing in different countries worldwide. So we have MFIs that, through an integrated approach provide their customers with financial and non-financial services (such as social mediation, creation of groups, leadership development services for businesses, training on commercial marketing and social services, education, health-care services and food education). The MFIs adopting a minimalist approach provide only financial services, namely credit and savings. In Corsi M. (2008), Women and micro-finance: a look at the Mediterranean countries, Rome, Aracne, p. 32.

51. Lämmermann S. and Ribbink G. (2011), Micro-finance and business. Development services in Europe. What can we learn from the South?, European Micro-finance Network, p. 7.

52. Santangelo, F. (2013), Financial services, in Pizzo G. and Tagliavini G. Dictionary of micro-finance, types of micro-credit, Rome, Carocci. 
53. Nardone A. and Costantini M. C. C. (2011), BDS for inclusion: the case of Fondazione Risorsa Donna, European Micro-finance Network electronic Research Bulletin, Brussels, III, pp. 4-7.

54. Nardone A. and Costantini M. C. C. (2011), BDS for inclusion: the case of Fondazione Risorsa Donna, European Micro-finance Network electronic Research Bulletin, Brussels, III, pp. 4-7.

55. Santangelo, F. (2013), Financial services, in Pizzo G. and Tagliavini G., Dictionary of micro-finance, types of micro-credit, Rome, Carocci, p. 761.

56. Lämmermann S. and Ribbink G. (2011), Microfinance and business. Development services in Europe. What can we learn from the South?, European Micro-finance Network, p. 34.

57. The European Micro-finance Network is the main European network created in 2003 to promote microfinance and fight against social and financial exclusion in the European Union. The EMN is active in promoting microenterprises and self-employment initiatives, thanks to the support of its members and their lobbying activity, and raises awareness on the need to create business-friendly regulatory frameworks that favour the development of microfinance in Europe. Its main activities are the capacity building actions of its members, information exchange, networking, advocacy at European level, text publication and dissemination, project implementation. www.european-microfinance.org.

58. Lobbezoo M. (2012), Volunteer versus paid coaches within micro-finance initiatives: What do we actually know about effectiveness?, European Microfinance Network eRB III, pp. 8-12.

59. European Commission (2013), Entrepreneurship 2020 Action Plan - reigniting the entrepreneurial spirit in Europe, COM (2012) 795 final, Brussels, http:// ec.europa.eu/enterprise/policies/sme/entrepreneurship-2020/index_en.htm.

60. EMN: Overview of the microcredit sector in the European Union 2010-2011, Romanian rank the fifth after Germany, France, Spain and Poland.

61. http://www.faer.ro.

62. http://www.antreprenoriat.faer.ro/.

63. www.eurom-consultancy.ro.

64. The EUCoGC provides a set of standards in terms of management, governance, risk management, reporting, and customer and investors relations that are common to the microcredit sector in the European Union. These standards are for the benefit of customers, investors, funders, owners and partner organisations. The code is primarily designed to cover non-bank microcredit providers which provide loans up to $€ 25,000$ to microentrepreneurs.

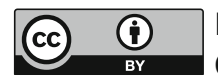

Except where otherwise noted, this work is licensed under a Creative Commons Attribution 3.0 Unported License. To view a copy of this license, visit http://creativecommons.org/licenses/by/3.0/ 